\title{
ETV1 Gene
}

National Cancer Institute

\section{Source}

National Cancer Institute. ETV1 Gene. NCI Thesaurus. Code C24377.

This gene is involved in transcriptional activation and spinal cord development. 